\title{
Forming Financial Vision: How Parents Prepare Young Adults for Financial Success
}

\author{
Bryce L. Jorgensen \\ New Mexico State University \\ David B. Allsop \\ Brigham Young University - Provo \\ Samuel D. Runyan \\ Brigham Young University - Provo \\ Brandan E. Wheeler \\ Mississippi State University \\ David A. Evans \\ Polldwetbrisiremsiadditional works at: https://scholarsarchive.byu.edu/facpub \\ Part of the Other Social and Behavioral Sciences Commons
}

See next page for additional authors

Original Publication Citation

Jorgensen, B. L., *Allsop, D. B., *Runyan, S. D., Wheeler, B., Evans, D. A., \& Marks, L. (2019).

Forming financial vision: How parents prepare young adults for financial success. Journal of Family and Economic Issues, 40, 553-563.

\section{BYU ScholarsArchive Citation}

Jorgensen, Bryce L.; Allsop, David B.; Runyan, Samuel D.; Wheeler, Brandan E.; Evans, David A.; and Marks, Loren D., "Forming Financial Vision: How Parents Prepare Young Adults for Financial Success" (2019). Faculty Publications. 4831.

https://scholarsarchive.byu.edu/facpub/4831

This Peer-Reviewed Article is brought to you for free and open access by BYU ScholarsArchive. It has been accepted for inclusion in Faculty Publications by an authorized administrator of BYU ScholarsArchive. For more information, please contact ellen_amatangelo@byu.edu. 


\section{Authors}

Bryce L. Jorgensen, David B. Allsop, Samuel D. Runyan, Brandan E. Wheeler, David A. Evans, and Loren D. Marks 


\title{
Forming Financial Vision: How Parents Prepare Young Adults for Financial Success
}

\author{
Bryce L. Jorgensen ${ }^{1}$ (D) David B. Allsop ${ }^{2} \cdot$ Samuel D. Runyan ${ }^{2} \cdot$ Brandan E. Wheeler $^{3} \cdot$ David A. Evans $^{4}$. \\ Loren D. Marks ${ }^{2}$
}

Published online: 16 April 2019

○) Springer Science+Business Media, LLC, part of Springer Nature 2019

\begin{abstract}
The current study used a multi-generational and qualitative approach to examine perceptions of what parents/grandparents taught their children/grandchildren about finances. Qualitative interviews were conducted with 98 participants consisting of 77 college students, 13 parents and eight grandparents. Team-based qualitative analyses of these interviews revealed three consistent themes: (1) the importance of setting financial goals, (2) planning and acting to meet financial goals, and (3) understanding the time value of money. About $70 \%$ of participants mentioned at least one of the three main themes in their interviews. In general, parents and grandparents held regret for not providing financial lessons earlier in life, while students demonstrated gratitude for helpful conversations and good examples from parents. Implications are discussed for practitioners, educators, and parents.
\end{abstract}

Keywords Financial socialization $\cdot$ Financial goals $\cdot$ Parenting $\cdot$ Family finance $\cdot$ Emerging adults $\cdot$ Qualitative

Recent research shows that many emerging adults lack important financial knowledge and abilities (Babiarz and Robb 2014; Lusardi et al. 2010). This is especially problematic as financial challenges have become more complex, including the repayment of sizable student loan debt and planning for future goals (e.g., home purchases, retirement, etc.) (Jorgensen and Savla 2010; Xiao et al. 2014). As researchers, practitioners, educators, and policy makers seek to improve financial knowledge, attitudes, skills, and behaviors in young adults, research suggests that a focus on financial socialization in the home is especially valuable. To this end, studies have shown that children learn more about finances from their parents than from any other sources (Jorgensen and Savla 2010; Kim et al. 2011; Lusardi et al. 2010).

Bryce L. Jorgensen

brycej@nmsu.edu

1 New Mexico State University, 940 College Drive, GTH 308 , Las Cruces, NM 88003, USA

2 Brigham Young University, 2092C JFSB, Provo, UT 84602 , USA

3 Mississippi State University, 255 Tracy Dr, Mississippi State, MS 39762, USA

4 Purdue University, 812 W. State Street, West Lafayette, IN 47907-2060, USA

\section{Literature Review}

Parents have the greatest impact on children's financial learning through teaching and role modeling (Clarke et al. 2005; Grinstein-Weiss et al. 2012; Jorgensen and Savla 2010; Serido et al. 2010). The financial knowledge, attitudes, and behaviors developed during childhood often carry into adulthood, and influence financial independence and financial capability during adulthood (Bucciol and Veronesi 2014; Grinstein-Weiss et al. 2012; Kim and Chatterjee 2013). The financial independence and capability first learned in childhood are important to individual wellbeing and influence many other aspects of life, including marriage and family relationships (Britt and Huston 2012; Dew 2007; Kerkmann et al. 2000). In contrast, a lack of financial competence is often followed by personal, familial, and societal problems (Clarke et al. 2005; Hira 2012; Xiao et al. 2014).

As a part of teaching children financial knowledge and fostering capability, it is important for parents to help their children learn how to set financial goals and to plan and act for the future. As children approach the transition into adulthood, it is important for parents to help their children be prepared to use their financial skills and knowledge to accomplish their future goals, such as gaining a college education, establishing financial independence, and acquiring 
assets including home ownership (Hillman et al. 2015; Kim and Chatterjee 2013; Kim et al. 2011). Helping children prepare for their financial future also includes assuring they will have access to financial resources as adults (Huang et al. 2015; Jorgensen and Savla 2010). Setting financial goals and then planning and acting to meet those goals are key aspects of financial literacy (Jorgensen and Savla 2010) and appropriate socialization in these domains can have longterm impacts on children's futures (Grinstein-Weiss et al. 2012). Specifically, those who learn to plan ahead financially have greater financial security and stability (MacEwen et al. 1995), as well as greater overall financial well-being (Drever et al. 2015). Thus, it is important for parents to financially educate their children regarding how to make financial plans and prepare for adulthood. This is especially true because a lack of financial education hampers the achievement of longterm goals, such as home ownership, educational pursuits, retirement planning, and asset accumulation (GrinsteinWeiss et al. 2012; Huang et al. 2015).

One of the most common and vital ways parents can teach their children about financial planning and goal setting is by teaching children to save and invest (Bucciol and Veronesi 2014; Hira et al. 2013). Providing opportunities for children to save and invest teaches them how to have self-control and gain future-orientation perspectives (Drever et al. 2015), accumulate assets to take care of their future needs (Bucciol and Veronesi 2014; Friedline 2015; Kim and Chatterjee 2013), and establish healthy saving and investing behaviors in adulthood (Bucciol and Veronesi 2014; Hira et al. 2013). In addition, when children have opportunities to save and invest, they will be better prepared to pay for college expenses and avoid excessive student debt (Hillman et al. 2015; Huang et al. 2015; Jorgensen and Savla 2010; Kim et al. 2011); a financial goal that is common in most families (Huang et al. 2015). As parents help their children learn principles of saving and investing, including an applied understanding of the time value of money and compound interest, it is important to help children begin saving at an early age (Drever et al. 2015; Friedline 2015; Kim et al. 2011). Providing children with the opportunity to practice saving and investing within the home lays the foundation for their future financial independence and wellbeing (Beverly and Burkhalter 2005; Grusec and Hastings 2015).

The theoretical foundations for the importance of teaching children within the home about financial planning and goal setting are rooted in several theories. Our study primarily uses Gudmunson and Danes' (2011) family financial socialization model to explain the processes of financial education that occur through implicit family interaction and explicit parental teaching. Researchers have found that as parents teach their children to set financial goals and plan for the future, parents should both implicitly model healthy financial planning behaviors and explicitly use a variety of methods to teach their children (Bucciol and Veronesi 2014; Friedline 2015; MacEwen et al. 1995). This study also integrates some foundation elements of social learning theory (Bandura 1986) in that most extant related studies and our own empirical data indicate that a parent's financial behavior may have a strong influence on children's financial learning. As children observe and interact with their parents in a familial and social context, children tend to adopt the attitudes and behaviors they observe in their parents. Further, these tendencies are not temporary. Researchers have found that children whose parents model healthy financial behaviors will likely imitate those behaviors not only in childhood but are likely to carry them into adulthood (Jorgensen et al. 2017; Shim et al. 2010).

The purpose of the current study is to qualitatively describe the socialization of financial planning, goal setting, and goal-related action in the context of the family. Specifically, we describe what emerging adults, parents, and grandparents repeatedly reported about parental socialization regarding the importance of setting financial goals, planning and acting to meet financial goals, and understanding the time value of money. The current study provides a deeper understanding of the influence parents can have on their children when it comes to helping children develop a healthy financial vision for their lives. We hope the experiences of our three generations of participants (college-aged children, parents, and grandparents) can provide insight into family financial socialization and offer some implied directions for future research on this vital topic.

\section{Methods}

\section{Sample}

The convenience sample for the full study, the Whats and Hows of Family Financial \$ocialization project (LeBaron et al. 2018), included 153 participants, including 128 undergraduate students (ages 18-30) enrolled in family finance classes at three universities (a private university in the West interviewed January-May 2015, a public university in the Midwest interviewed October-December 2016, and a state university in the Southwest interviewed October-December 2016). Family finance classes were the source of recruitment as (1) several project leads taught these classes and could access this population and (2) the research was relevant to student learning. Students were offered extra credit for participation. However, not all students who agreed to participate were interviewed-purposive sampling was used to increase the racial and ethnic diversity of the sample. Additionally, 17 parents and eight grandparents of these students were also interviewed, thereby providing reports and perspectives from three generations (college student, 
her/his parent, and her/his grandparent). The full study sample was $63 \%$ female (97 of 153) and 37\% male (56 of 153). The racial composition of the sample was $71 \%$ (108 of 153) White and 29\% (45 of 153) ethnic and/or racial minority (including African American, Asian, Latino/a, and Pacific Islander) individuals.

From this larger project, a sample of participants who spontaneously offered comments related to the current study's concern of "Financial Vision" were employed. Daly (1992) has stated, "With qualitative methods, the focus is not on identifying structural or demographic trends in families, but rather on the processes by which families create, sustain, and discuss their own family realities" (p. 4). In the present study, the family "reality" of concern is the creation of "Financial Vision." Interview-based qualitative methods are of special utility in describing, capturing, and reflecting the meaning making that occurs in connection with "Financial Visions." This sample included 98 participants from 95 interviews (see "Appendix" section), consisting of 77 students, 13 parents, and eight grandparents. More specifically, the "Financial Vision" sample included 33 males and 65 females (Table 1). The racial composition of the sample was 63\% White (62 of 98) and 37\% (36 of 98) ethnic and/or racial minority (including Asian, Latino/a, Pacific Islander, and African American) individuals. The sample included $65 \%$ from a private Western university, $24 \%$ from a public Midwest university, and $10 \%$ from a state university in the Southwest (Table 2).

\section{Procedures}

Semi-structured qualitative interviews were conducted by trained team members either face-to-face or over-the-phone. All in-person interviews were conducted in a research office on a university's campus, with student interviews typically lasting 15-30 min and parent/grandparent interviews typically lasting 30-45 min. Each interview began with two open-ended questions: (1) "What did your parents teach you about money?" and (2) "How did they teach you those things?" Follow-up questions were then asked to garner further information from participants based on their
Table 2 Participant university locations

\begin{tabular}{llll}
\hline & Western private & Midwest public & Southwest state \\
\hline Count & 64 & 24 & 10 \\
$\%$ & $65 \%$ & $24 \%$ & $10 \%$ \\
\hline
\end{tabular}

Counts and percentages are for current subsample of the present study; parent and grandparent location associated with student locale (i.e., parent or grandparent could have lived in different location than student)

responses. In addition to the previous two questions, parent and grandparent interviews also focused on the queries: (1) "What did you teach your children about money?" and (2) "How did you teach those things?" Interviews were digitally recorded and then transcribed verbatim. Data were coded and analyzed using a systematic, team-based methodology, described in the next section.

\section{Qualitative Coding and Analyses}

A team-based approach to qualitative data collection, coding, and analysis was intentionally designed to produce "more valid, reliable, and rigorous qualitative research" than the solo researcher approach often employed in qualitative research (Marks 2015, p. 494). Based on Marks (2015), four methodological phases were followed: (1) "Developing the interview protocol and defining the sample," (2) "data collection and coding," (3) "caching the rocks and gems for each theme," and (4) "placing the gems in the qualitative research crown" (pp. 496-497). This team-based approach integrates several strategies for providing greater reliability, including: (a) developing a detailed audit trail for sampling, questionnaire usage, and qualitative coding that demonstrate and provide a "replicable method of inquiry" (Marks 2015, p. 499); (b) having a diverse qualitative research team in terms of project related diversity (i.e., researchers came from a variety of financial backgrounds and family structure types); and (c) coding in pairs with a focus on interrater reliability that allows for multiple voices to be heard and conveyed while providing checks and balances for the biases of each team member. Detailed explanation of the
Table 1 Gender and race participant characteristics

\begin{tabular}{lccccccc}
\hline & Male & Female & White & Hispanic & Asian & Pacific Islander & $\begin{array}{l}\text { African } \\
\text { American }\end{array}$ \\
\hline Count & & & & & & & \\
Total count & 33 & 65 & 62 & 21 & 6 & 3 & 6 \\
Student & 27 & 50 & 48 & 16 & 6 & 3 & 4 \\
Parent & 4 & 9 & 8 & 3 & 0 & 0 & 2 \\
Grandparent & 2 & 6 & 6 & 2 & 0 & 0 & 0 \\
$\%$ & $34 \%$ & $66 \%$ & $63 \%$ & $21 \%$ & $6 \%$ & $3 \%$ & $6 \%$ \\
\hline
\end{tabular}

Counts and percentages are for current subsample of the present study 
four-phase, 34-step process are available (Marks 2015, pp. 494-495). However, in overview, the qualitative data were analyzed by ten research team members, who were divided into five coding pairs. Each member of the coding pair independently open coded their assigned interviews line-by-line and then met with their partner to review their open codes in a check and balance system, resolving discrepancies as they arose. Composite inter-rater reliability was very high, over.90 (approximately 95\%), for the themes presented in the present article. Coded excerpts were cataloged employing NVivo 11 qualitative software. Only emergent themes documented by all team members and pairs were "designated with the carefully reserved appellation of core theme" (Marks 2015, p. 503, emphasis in original).

Initially, seven overarching themes emerged from analysis of the interviews including the theme of Financial Vision (for details on the other themes, see LeBaron et al. 2018). Financial Vision was operationalized as teaching which focused on long-term financial outcomes and preparing to meet those outcomes. After coding for the seven overarching themes, further coding of hundreds of excerpts ("nodes") from Financial Vision were conducted to identify further themes. From this coding, three components of Financial Vision emerged: The Importance of Setting Financial Goals, Planning and Acting to Meet Financial Goals, and Understanding the Time Value of Money. A numerical content analysis (Table 3) revealed that the theme of The Importance of Setting Financial Goals was identified a total of 171 times, an average of 2.2 references per interview (RPI). Planning and Acting to Meet Financial Goals was identified by our team 167 times, with 2.2 RPI. The theme Understanding the Time Value of Money was identified by our team 87 times, with 1.7 RPI.

\section{Findings}

In this section we present each of the three identified themes relating to "Financial Vision" with 20 supportive and illustrative excerpts from the participants' interviews. In our intentional decision to present numerous excerpts of primary data, we seek to employ a "choir director" approach as opposed to that of a "diva soloist" who prefers researcher interpretation and explanation to participants' voices (Marks 2015 , p. 503). We prefer this approach as it allows readers to repeatedly hear participants' own voices instead of researcher explanation, thus allowing readers to better understand participants and the themes identified. Pseudonyms are used when sharing participant excerpts.

We first present findings for the theme of The Importance of Setting Financial Goals, a theme concerning making future aspirations involving finances. Second, we present findings for the theme of Planning and Acting to Meet Financial Goals. This theme concerns ensuring future aspirations are realized through financial planning and behavior. Lastly, we present findings for the theme Understanding the Time Value of Money, a theme which addresses participants' socialization about earning or paying interest.

Interview excerpts are accompanied with various identifiers. All quotes identify the individual's gender. Most quotes identify the age of the participant but, in some cases, ages were not available. Family member type is, by default, a student unless noted as a parent or grandparent.

\section{Theme 1: The Importance of Setting Financial Goals}

Throughout the coding process, $82 \%$ of participants in the subsample mentioned that the importance of setting financial goals was taught in their families. Amy, a 19-year-old female, said,

Even though my parents have a lot of money, they don't like spending it on unnecessary things, which I appreciate. I definitely learned by their example that we don't need everything that we can afford. [W]hen we would get money for birthdays or something, they would tell us that it was important to save and have a goal to save for.

At least nine participants discussed paid work in the context of setting financial goals, including Ally, who shared how her parents encouraged her to set goals when she started babysitting.
Table 3 Numerical content analysis

\begin{tabular}{lllll}
\hline Theme & \# References & \# Sources & $\begin{array}{l}\text { \% Interviews } \\
\text { with theme (\%) }\end{array}$ & Average \# Ref. per Int. \\
\hline Set financial goals & 171 & 78 & 82 & 2.2 \\
Plan to meet financial goals & 167 & 75 & 79 & 2.2 \\
Time value of money & 87 & 50 & 53 & 1.7 \\
Totals (averages) & $425(141.7)$ & $203(67.7)$ & $214(70)$ & $6.16\left(2.1^{\mathrm{a}}\right)$ \\
\hline
\end{tabular}

Calculations were made based on the 98 interviews that spontaneously addressed "Financial Vision," not on the 153 total interviews conducted in the larger study

${ }^{\text {a }}$ Represents weighted average 
As I started getting older and started babysitting, my parents really encouraged me like, "Well, if you want money to do something, [try something like] babysitting. You can save some of your money or maybe think about what it is that you want to buy and stick it in your little jar and set aside your tithing." And they were pretty good about... reinforcing the need for me to earn my own income and do that but I always knew that they would be there to back me up if I didn't have enough money to do something or when I wanted to go to [a summer camp] and I couldn't pay for all of it. They were good about [saying], "Okay, well, you can chip in half and we'll do half."

In addition to being taught the general principle of having an individual financial goal, at least two families had a shared financial goal. The above participant, Ally, also discussed, "I was pretty conscious of the fact that we were trying to save money to be able to go to Disneyland [as a family]."

At least nine participants discussed a parent-child partnership when it came to financial goals. A 53-yearold mother, Alma, shared how they paired up with their children to achieve the child's goal of going to Especially for Youth, a week-long summer camp for teenagers. The mother explained, "So my kids, to go, we paid half of the money. They had to pay for the other half, which would include saving a little every month. So that was a goal that they had to do [for] a whole year. And that's something they enjoyed. So it gives them more meaning when they pay for it."

In a similar example, an 80-year-old grandmother, Adeline, told of a time she worked with her children on creating their own vacation destination as a financial goal,

There was a time when we were moving to South Africa and we were going to travel. We let them choose some places that they wanted to stop. London was one of them that they chose. They chose Holland, they chose Greece, they chose Israel, there was another place, and we told them we could stop there and suggested they earn some of the money. We hung a map on the wall with the pins with each of the places we were going to stop and as they earned their money they had a thread or a string that would get them to the next place as they earned enough money. So, it was more fun and a game than us saying they had to do it... if they wanted the money to spend then they would need to work for it and they did. They did jobs and stuff for that. So we didn't just give them money, they earned it.

Not all teaching was positive. At least two participants expressed mistakes they or others had made related to financial goal setting. One male parent, Kurt, shared how their using credit cards poorly negatively influenced their children's views of making purchases. He explained,

When [our kids] were young, I think we made one fatal mistake...we had just finished college, we used our credit card quite a bit. Not excessively, but it was, you know, "buy something this month and then pay it off." So the kids saw more when they were young about choosing [the] card. And so in their tween type of years when they were really starting to talk about "lets buy nice shoes, or fingernails or designer whatever." If we say no that doesn't really fly, they would say "just use the card."

During another conversation, Kurt explained how they failed to teach their children about setting goals to invest for their future. He states,

On the investing side they know that Mom and Dad are saving for retirement, but we have not talked to them about "you know as soon as you can get $\$ 1000$ saved put it in an IRA." Add a little bit here or there, start when you're 21 . We haven't done that, which we still have time because none of them are 21 yet, but that's something that we did not engrain early. So I'm hoping, well now I have to fly by the seat of my pants and say "remember start saving now for when you're 60." Which is hard for them to fathom but that's just how you have to play the game now. It's what you need to do. So in that part we have been lacking...

As described above, various savings strategies were employed by parents to encourage their children to save. In other instances, parents were remorseful about poor spending behaviors. Those who had well-defined, common-interest goals seemed to be the most successful in forming early, positive financial management behaviors among their children. The next theme Planning and Acting to Meet Financial Goals highlights how these goals were met.

\section{Theme 2: Planning and Acting to Meet Financial Goals}

Planning and Acting to Meet Financial Goals was the second theme that emerged from the analysis and was mentioned by $79 \%$ of participants in the sample. This theme is closely associated with The Importance of Setting Financial Goals. While Setting Financial Goals addressed a vision for one's future, the theme Planning and Acting to Meet Financial Goals addressed putting future financial goals into action in the immediate present. A 76-year-old grandmother, Ruby, stressed the importance of having a financial plan with her children, 
We would have talks and plan about what was expected. We would plan out who would do what to earn so much money or whatever. We felt that they should pay their way. We grew up paying our way!... In our planning meetings, we would talk about, "What do you want to do and how are you going to get the money to do that?" We would talk that through.

This idea of having a plan and "paying [one's] way" was echoed by Neal, a 23-year-old male, who recalled,

[Growing up] there's certain things that I wanted and [my parents] made me save up to pay at least a part of those. So I moved to America when I was sixteen. When I wanted to go back to England in the summer I had to pay for at least a part of my ticket. It's usually around $\$ 1500$ to go back so I had to pay part of that. Just things like that, they made sure that I knew that this part was my responsibility and then [they] direct[ed] me to know what I needed to do make up that responsibility.

Looking back on raising their children, Ron, a 55-year-old father, shared how having financial goals was important in their parenting. He said,

"I guess the point is, we helped them see what they needed to do to achieve the goals that they had and then help them do that. [We wanted to] help them work those plans and achieve those goals."

For Alex, a 23-year-old male, planning and acting to meet financial goals was associated with financial planning later in life. He explained how his parents' emphasis on planning affected his later buying habits,

My parents taught me [about] wise planning and thinking ahead. Look ahead to what you actually need the money for. I have been wanting to buy an acoustic guitar for a while but I just haven't done it because... [it's] just going to drain my money. And it's not part of my goals for the future with school and family, which are far more important than a nicer guitar.

Similarly, Teresa, a 52-year-old mother, shared how achieving financial goals was adapted for each child. She recalled,

[How to achieve goals] really depended on each child, what their activities were, and what was reasonable. I think that as a rule, the general rule as parents [was that] we worked with the individual child to come up with what was a reasonable goal.

Kurt, a father quoted previously, shared an experience illustrating that planning and acting to meet financial goals means being disciplined by sometimes saying "no." He said,
So from the time they could understand money, if they would ask for something at the store... we would ask, "How much is it?" So they had to identify price. So we're helping them identify what value supposedly it holds according to the company who's selling it. And then we would say, "How much money do we have now, and what did we come to the store to get?" [W]e would talk about that. And then we would ask, "Is this item on our list?" and they would say "No." Then we would talk about being able to plan ahead basically. So we were trying to teach them very young to avoid impulse buying. That didn't always work, sometimes they were persistent, and we realized that we had a little extra so we... you don't want to say no all the time... [We] wanted [them to]... know, "Realize that you need to say no once in a while so that you can say yes to the even better things that might be more longer lasting to you."

In addition to a link between financial planning and discipline, planning and acting to meet financial goals were linked to a focus on saving for Gus, an 88-year-old grandfather. He discussed this idea of saving and planning when he said, "I told [my children] to work around the home and then when they got old enough to get a job... save your money cause you're gonna need to get money to go to college, you're gonna need money to do this or do that, pretty much anything it takes money."

Echoing this idea of saving and planning, William, a 24-year-old male, shared,

I wanted to buy a Game Boy Advance [electronic toy] when I was 9 years old. So my parents said, "Yeah, you can definitely have that. You'll have to save up for it though." So every month I got my little bit of allowance, I'd do a few more chores on the side to get a few more dollars, and I can still remember purchasing the Game Boy. Even after that moment, like when I got a job for myself, I feel that event impacted me to save all [my] money, and... use it for something [I] want later.

Kurt, one of the fathers quoted earlier, recalled how he regrets not being taught about planning ahead for financial goals by his parents and how he had to learn instead from life experiences that might have cost him a lot of money. He recalls,

[Planning ahead is] something I did not get from my parents. With their limited education, it's not because they didn't go to college but there is something about higher education that kind of refines your mind to focus on financial goals for the most part. To help you know how to better manage money. Because first of all it's expensive to graduate college so you have to find a way to get through that anyway. So then you learn the 
value of that long-term thinking. So when I went to college I was kind of like "oh they're going to give me student loans? Awesome!" So we were no exception but we look back and think we could probably have lived on half. Half is really what we needed from what we borrowed. We weren't smart enough.

While setting financial goals was reportedly important, helping children/grandchildren to plan and act in ways that would help to meet these goals was a second vital and recurring theme in the participants' responses. The ideas of putting these plans into action by establishing steps for achieving the goals, practicing discipline, and linking the goals with the actions were important to many of our participants as they strove to teach their children about finances. However, these examples reflect actions taken in the present to meet short-term, mostly non-essential goals. The following section describes the more challenging aspects of helping young savers understand the long-term benefits of sound financial management.

\section{Theme 3: Understanding the Time Value of Money}

Our third and final theme, Understanding the Time Value of Money, was mentioned by $53 \%$ of the participants in the sample. Understanding the Time Value of Money was defined as the idea that money held in banks or investment vehicles can grow wealth or that borrowed funds typically accumulate interest. At least three participants were taught this principle through hands-on experience. Alma, a mother whose experience we shared previously, taught her children through this experiential method:

We had a lesson where we put in a jar, one dollar. And I think it went for 30 days. And every day we're adding ten percent, which is highly exaggerated, but we really wanted them to see the difference. So we did 10 percent every day. Every day for...30-60 days. But by the end, I mean you're adding that 10 percent, 10 percent, 10 percent, it adds up. So, they were able to see the amount of money that was in there and how the money in savings is growing. Leave it there, and that money is growing. Savings doesn't get that much, but we wanted them to make sure to leave it there so the money can grow.

A female participant (\#8) similarly mentioned how a family bank helped her learn about the time value of money, "[My Dad] really wanted to do this family bank... and teach us about savings and interest... so every... allowance [my parents] would sit down and... put [some of it] directly into [the family bank]."

At least seven other families took the approach of using commercial financial vehicles to teach their children about the benefits of interest. Alex, a student we quoted earlier, recalled,

My family has done a lot of shows here in the local theater... so whenever I did a show I would get that money and about half of that money went towards purchasing government bonds. And so that was the first time I really ever experimented with investing and my parents just gave me the basic concept that you put your money in and wait a really long time and when you go to take it out, your money essentially doubled. They told me that with government bonds your money is typically a lot safer than corporate bonds or stocks. So when I was pretty young I understood the basic concept of investment. I was about 10 or 11 years old.

Joseph, a 22-year-old male, similarly shared how he used commercial investments due to his father's influence. He recalled, "So my Dad, he's not an economist or anything, but he definitely taught me in high school to start investing, so I started investing in high school, I still have been investing money."

In addition to family banks or commercial investments, Kody, a 21-year-old male, recollected learning about the time value of money by watching his parents manage investments. He said,

I knew my Dad invested. With the first company he worked for he was involved in the stock shares... he could get discounted stocks from that company and he taught me a little bit about that early on. Now that I' $m$ in school I understand them a little better. But I remember he told me what a dividend check was because he got that in the mail twice a year and I saw how much they were for and I was really impressed because I thought, "He's just getting that just from having [bought the stocks]... and he's not having to do anything extra... [T] hat is a real check for real money." And I thought that was really neat and that kind of piqued my interest in investing.

Nate, a 23-year-old male, similarly reported,

[My Dad] and my Mom, the first thing they do in the morning is read scriptures and the second thing they do is look at stocks and then they go eat breakfast. I guess him being wise in his investment kind of shows me the importance of investing.

Besides being an example or providing hands-on experience, Nancy, a grandmother, remembered that her parents simply told her about the importance of the time-value of money. She shared, "We tried to explain that when you are in debt you are paying interest. When you are in investments you are getting interest." 
Paula, a female student, expressed regret in not asking more about investing and that her parents would have taught her more. She recalled,

Yeah, I remember going with them to the bank with the first \$2000 I had earned from working in the first 8 or 9 months. My dad took me to the bank and we set up two certificates of deposit and I remember him trying to explain to me what it was but I remember not really following but not wanting to question because I didn't really think much of it at the time. I wish I had asked more at the time in terms of what I was doing with that money, which was nice, because he actually put it into a mutual fund and it's actually made money over the years which is nice. Now it's my husband and my account. But I wish they would've taught me more about investing because now as an adult, they have been very smart with their money and investing and I didn't hardly know anything about investing until about 2 years ago when I actually kind of got interested in it. Wise insurance and all that stuff, which I hadn't really thought of when I was younger.

A general theme from the results suggests that parents and grandparents were highly motivated by their own past experiences and possessed a generative desire to pass valuable information on to their children that would benefit their children and grandchildren financially in the future. Some emerging adults in the study reported a sense of gratitude for the efforts their parents made to teach them sound financial practices (explicitly or implicitly), and how they still employ those practices today.

\section{Discussion}

The current study qualitatively described financial socialization in the context of the family. More specifically, we described what emerging adults reported about lessons their parents taught them regarding the importance of setting financial goals, planning and acting to meet financial goals, and understanding the time value of money. The study also included responses from parents and grandparents regarding the financial strategies they employed to teach concepts considered to be the most important for their children to learn (e.g., saving up for and buying their own highly desired goods, saving up and contributing toward desired activities like travel and special summer camps). It is important to note that visions, goals, and lessons about the time value of money were taught (and received) quite differently from one family to the next. While the general topics may have been similar, the specific teachings and teaching methods were not the same. In some instances, explicit communication was not reportedly necessary to have an impact on the receiver of the information (e.g., a son observing the consistent receipt of dividend checks by his father, or a daughter observing the daily financial practices of her parents). When financial knowledge was imparted explicitly, it typically came in the form of planning meetings or individual goal-setting discussions

Having a vision for the future aids in goal setting by providing a direction towards which the individual can focus their attention in the face of competing interests. Setting goals and then establishing action plans to accomplish those goals provides a foundation for realizing one's financial vision. Indeed, the current study provides a deeper understanding of the influence (positive or negative) parents can have on their children when it comes to having and actualizing a financial vision in their lives.

The importance of setting goals and planning how those goals would be met came up many times in the interviews (99 times and 90 times, respectively). Reported goals ranged from going to college, staying debt free, and saving for desired purchases such as summer camp fees or vacations. Sometimes parents suggested goals for their children, other times parents helped children identify their own goals, and other times families had a shared financial goal.

Understanding time value of money, along with compound interest, motivates people to save and invest as early as possible while staying out of debt (Kim and Chatterjee 2013). This theme was addressed more than 70 times by participants. More specifically, participants repeatedly mentioned the importance of putting money aside and letting it grow. Having money work for you instead of spending it all now was emphasized by parents and grandparents. Many emerging adults reportedly learned this principle through the example of their parents as well as through direct teaching from parents. To help their children learn to save and plan for the future, some parents created their own private financial structure (referred to in some instances as "the family bank") while others employed the use of traditional banks and simple investment vehicles such as government bonds.

\section{Implications}

The findings reported here have important implications for parents, families, and practitioners who work with families. Helping emerging adults form a financial vision of their future lays the foundation for future financial independence and wellbeing. However, this foundation needs to begin early in life. If a child wants to attend college, and the parents expect the child's help in paying for this college education, saving money needs to be prioritized and commenced long before the child reaches his/her senior year of high school. These discussions and lessons can begin in the early teenage years, or even sooner, to help the child establish these goals, to develop a plan, and to act on and achieve that plan and the 
subsequent end goal(s). Through these processes, leveraging the positive effects of compound interest can be prioritized as the child watches the amount of money saved grow over time-while striving to avoid unnecessary debt. Many parents already intentionally teach their child to save a portion of their money, yet the purpose for this saving is not always made clear. Helping parents to explain the why for saving money (e.g., setting financial goals), while also developing a plan to achieve these goals can help to motivate a child or adolescent into adopting these positive financial behaviors. Young adults, who learned explicitly from their parents, believe they have better financial attitudes and behaviors than those who reportedly learned only through implicit means (Jorgensen and Savla 2010). Indeed, Solheim et al. (2011) suggest that how parents teach their children about finances may be more important than what they teach their children. As parents are more intentional in their teaching of financial principles, a strong foundation is more likely to be set for their children's (and grandchildren's) future financial wellness.

Because parents tend to have the greatest impact on their children's financial wellness (Grinstein-Weiss et al. 2012; Serido et al. 2010), practitioners and educators can support parents as they teach their children to set financial goals, to plan and act to meet those financial goals, and to understand and utilize the time value of money and compounding interest in their own favor. Parents are the primary source for children to learn about money, both through teaching and via role modeling behaviors (Grinstein-Weiss et al. 2012; Serido et al. 2010), yet many parents may not feel comfortable discussing finances with their children. Reasons frequently reported for this parental discomfort include not wanting children to be concerned with financial issues, parents lacking their own understanding of financial concepts, parents not practicing ("living out") positive financial behaviors themselves, and parents considering money to be a taboo topic (Romo 2011).

We think it noteworthy that Serido et al. (2010) found the quality of parent-child communication about finances was an important predictor of young adult's overall financial well-being. Practitioners and educators can help parents to overcome some of the aforementioned concerns by providing workshops on how to discuss money with children and by providing information or resources that can help parents more effectively communicate positive financial behaviors to their own children. Not all families need to provide a "family bank," as some participants in the current study did, but finding ways to visually illustrate that money can grow over time can be a valuable teaching tool. In addition, utilizing certificates of deposit or other interest-earning vehicles on behalf of children can be beneficial. There are also valuable online tools, such as compound interest calculators, that can be used to highlight how interest can be a valuable tool for future financial wellbeing - or the compounding interest on debts can be counterproductive, if not crushing. Introducing these educational resources to parents can help them to feel more comfortable as they discuss finances with their children.

Practitioners and educators can also prompt parents to explore their own views and beliefs about money. Money tends to have powerful symbolic meanings, that influence how people treat and discuss it (Shapiro 2007). One possibility is to encourage parents to explore their history with money, including recalling first memories of money, reflecting on how their parents talked about money, and remembering disagreements about money, etc. (Shapiro 2007). By exploring and better understanding their own beliefs and histories regarding money, parents may be able to more effectively teach their children about money, including the sharing of their own experiences with money and how these experiences have positively and/or negatively influenced them and their own well-being.

Helping parents teach their children these valuable financial lessons can benefit not only the children, but also the parents and their relationship with their children. Helping to set family and individual financial goals and developing a plan to meet those goals can allow parents to bond with their children while working towards these goals. At the same time, such lessons can help children develop the financial knowledge, attitudes, and behaviors needed later in life. The financial knowledge, attitudes, and behaviors developed during childhood often carry into adulthood, not only affecting the financial independence and capability of adults (Bucciol and Veronesi 2014; Grinstein-Weiss et al. 2012; Kim and Chatterjee 2013), but also influencing the quality of their marital and family relationships (Britt and Huston 2012; Dew 2007). In summary, improving financial behaviors early in life has the potential to improve other aspects of their life, not only financial outcomes. This socialization process starts in the home with parents leading the way.

\section{Limitations}

This study has several limitations. First, our study only included university students enrolled in a family finance class. Although students were interviewed from multiple universities, those taking a family finance class could be similar in their interest in this topic. Other college students, or emerging adults who choose not to attend college, could be qualitatively different. Similarly, parents or grandparents of college students may be more likely to teach their children the importance of having financial goals and planning for the future than parents of emerging adults who do not attend college. A second limitation is that the qualitative interviews were based on subjective, retrospective reports. Students, parents, and grandparents may have remembered experiences differently than they actually 
occurred. Research indicates that we all tend to engage in variations of revisionist history, often without being fully aware that we are adjusting events and details (Gilbert 2006). Finally, there was a relatively small sample of parents and grandparents. Although we seemed to have enough multigenerational qualitative data, interviewing additional parents and grandparents may have provided additional insights. We encourage future research to include a larger parent/grandparent sample.

\section{Conclusion}

Helping children plan for the future through setting financial goals and planning how to accomplish their goals can lead to feeling more in control financially and being more financially capable. Financial goals create a vision for an emerging adult's future, where they see themselves making wise financial decisions, leading to improved financial wellbeing. The experiences of our participants provide insight into how parents can shape the financial futures of their children. Additionally, educators and practitioners can assist parents in this effort. Energy spent on teaching younger generations to set wise financial goals and then to plan and act for the future can lead to a more secure financial future-more secure at individual, marital, intergenerational, and societal levels. Of all early influences, parents have the greatest impact on their children's financial vision, therefore, they should do all they can to positively influence the financial capability of their children and lay a sound foundation for future financial independence and wellbeing.

Acknowledgement We acknowledge the College of Home, Family, and Social Sciences at Brigham Young University for funds that helped support this project. We also acknowledge funds provided by the Camilla Eyring Kimball professorship in the School of Family Life at Brigham Young University.

\section{Compliance with Ethical Standards}

Conflict of interest Each author on this manuscript declares that he has no conflict of interest.

Ethical Approval All procedures performed in studies involving human participants were in accordance with the ethical standards of the institutional and/or national research committee and with the 1964 Helsinki declaration and its later amendments or comparable ethical standards.

Informed Consent Informed consent was obtained from all individual participants included in the study.

\section{Appendix}

There was a total of 98 participants, however, 95 interviews were conducted with the current subsample. The discrepancy is attributed to three interviews in which partners in romantic relationships were interviewed together. Hence the additional three participants over and above the 95 interviews. One of these partnered interviews came from a student couple, one from a parent couple, and one from a grandparent couple.

\section{References}

Babiarz, P., \& Robb, C. A. (2014). Financial literacy and emergency saving. Journal of Family and Economic Issues, 35, 40-50. https ://doi.org/10.1007/s10834-013-9369-9.

Bandura, A. (1986). Social foundations of thought and action: A social cognitive theory. Englewood Cliffs: Prentice Hall.

Beverly, S. G., \& Burkhalter, E. K. (2005). Improving the financial literacy and practices of youths. Children \& Schools, 27, 121-124. https://doi.org/10.1093/cs/27.2.121

Britt, S. L., \& Huston, S. J. (2012). The role of money arguments in marriage. Journal of Family and Economic Issues, 33, 464-476. https://doi.org/10.1007/s10834-012-9304-5.

Bucciol, A., \& Veronesi, M. (2014). Teaching children to save: What is the best strategy for lifetime savings? Journal of Economic Psychology, 45, 1-17. https://doi.org/10.1016/j.joep.2014.07.003.

Clarke, M., Heaton, M., Israelsen, C., \& Eggett, D. (2005). The acquisition of family financial roles and responsibilities. Family and Consumer Sciences Research Journal, 33, 321-340. https://doi. org/10.1177/1077727X04274117.

Daly, K. (1992). The fit between qualitative research and characteristics of families. In J. F. Gilgun, K. Daly, \& G. Handel (Eds.), Qualitative methods in family research (pp. 3-11). Newbury Park: Sage.

Dew, J. (2007). Two sides of the same coin? The differing roles of assets and consumer debt in marriage. Journal of Family and Economic Issues, 28, 89-104. https://doi.org/10.1007/s1083 4-006-9051-6.

Drever, A. I., Odders-White, E., Kalish, C. W., Else-Quest, N., Hoagland, E. M., \& Nelms, E. N. (2015). Foundations of financial well-being: Insights into the role of executive function, financial socialization, and experience-based learning in childhood and youth. Journal of Consumer Affairs, 49, 13-38. https://doi. org/10.1111/joca.12068.

Friedline, T. (2015). A developmental perspective on children's economic agency. Journal of Consumer Affairs, 49, 39-68. https:// doi.org/10.1111/joca.12062.

Gilbert, D. (2006). Stumbling on happiness. New York: Vintage.

Grinstein-Weiss, M., Spader, J. S., Yeo, Y. H., Key, C. C., \& Freeze, E. B. (2012). Loan performance among low-income households: Does prior parental teaching of money management matter? Social Work Research, 36, 257-270. https://doi.org/10.1093/swr/ svs016.

Grusec, J. E., \& Hastings, P. D. (2015). Handbook of socialization: Theory and research (2nd ed.). New York: Guilford Press.

Gudmunson, C. G., \& Danes, S. M. (2011). Family financial socialization: Theory and critical review. Journal of Family and Economic Issues, 32, 644-667. https://doi.org/10.1007/S10834-011-9275-y.

Hillman, N., Cast, M. J., \& George-Jeackson, C. (2015). When to begin? Socioeconomic and racial/ethnic differences in financial planning, preparing, and saving for college. Teachers College Record, 117, 1-28.

Hira, T. K. (2012). Promoting sustainable financial behavior: Implications for education and research. International Journal of Consumer Studies, 36, 502-507. https://doi.org/10.111 1/j.1470-6431.2012.01115.x.

Hira, T. K., Sabri, M. F., \& Loibl, C. (2013). Financial socialization's impact on investment orientation and household net worth. 
International Journal of Consumer Studies, 37, 29-35. https://doi. org/10.1111/ijcs.12003.

Huang, J., Nam, Y., Sherraden, M., \& Clancy, M. (2015). Financial capability and asset accumulation for children's education: Evidence from an experiment of child development accounts. Journal of Consumer Affairs, 49, 127-155. https://doi.org/10.1111/ joca. 12054.

Jorgensen, B. L., Rappleyea, D. L., Schweichler, J. T., Fang, X., \& Moran, M. E. (2017). The financial behavior of emerging adults: A family financial socialization approach. Journal of Family and Economic Issues, 38, 57-69. https://doi.org/10.1007/s1083 4-015-9481-0.

Jorgensen, B. L., \& Savla, J. (2010). Financial literacy of young adults: The importance of parental socialization. Family Relations, 59, 465-478. https://doi.org/10.1111/j.1741-3729.2010.00616.x.

Kerkmann, B. C., Lee, T. R., Lown, J. M., \& Allgood, S. M. (2000). Financial management, financial problems, and marital satisfaction among recently married college students. Journal of Financial Counseling and Planning, 11, 55-65.

Kim, J., \& Chatterjee, S. (2013). Childhood financial socialization and young adults' financial management. Journal of Financial Counseling \& Planning, 24, 61-79.

Kim, J., LaTaillade, J., \& Kim, H. (2011). Family processes and adolescents' financial behaviors. Journal of Family and Economic Issues, 32, 668-679. https://doi.org/10.1007/s10834-011-9270-3.

LeBaron, A. B., Hill, E. J., Rosa, C. M., \& Marks, L. D. (2018). Whats and hows of family financial socialization: Retrospective reports of emerging adults, parents, and grandparents. Family Relations, 67, 497-509. https://doi.org/10.1111/fare.12335.

Lusardi, A., Mitchell, O. S., \& Curto, V. (2010). Financial literacy among the young. Journal of Consumer Affairs, 44, 358-380. https://doi.org/10.1111/j.1745-6606.2010.01173.x.

MacEwen, K. E., Barling, J., Kelloway, E. K., \& Higginbottom, S. E. (1995). Predicting retirement anxiety: The roles of parental socialization and personal planning. Journal of Social Psychology, 135, 203-213. https://doi.org/10.1080/00224545.1995.9711424.

Marks, L. D. (2015). A pragmatic, step-by-step guide for qualitative methods. Current Psychology, 34, 494-505. https://doi. org/10.1007/s12144-015-9342-x.

Romo, L. K. (2011). Money talks: Revealing and concealing financial information in families. Journal of Family Communication, 11, 264-281. https://doi.org/10.1080/15267431.2010.544634.

Serido, J., Shim, S., Mishra, A., \& Tang, C. (2010). Financial parenting, financial coping behaviors, and well-being of emerging adults. Family Relations, 59, 453-464. https://doi.org/10.111 1/j.1741-3729.2010.00615.x.

Shapiro, M. (2007). Money: A therapeutic tool for couples therapy. Family Process, 46, 279-291. https://doi.org/10.111 1/j.1545-5300.2007.00211.x.

Shim, S., Barber, B. L., Card, N. A., Xiao, J. J., \& Serido, J. (2010). Financial socialization of first-year college students: The roles of parents, work, and education. Journal of Youth and Adolescence, 39, 1457-1470. https://doi.org/10.1007/s10964-009-9432-x.

Solheim, C. A., Zuiker, V. S., \& Levchenko, P. (2011). Financial socialization family pathways: Reflections from college students' narratives. Family Science Review, 16, 97-112.
Xiao, J. J., Chatterjee, S., \& Kim, J. (2014). Factors associated with financial independence of young adults. International Journal of Consumer Studies, 38, 394-403. https://doi.org/10.1111/ ijcs.12106.

Publisher's Note Springer Nature remains neutral with regard to jurisdictional claims in published maps and institutional affiliations.

Bryce L. Jorgensen is an Assistant Professor and Family Resource Management Specialist in the department of Extension Family and Consumer Sciences at New Mexico State University Bryce has published and presented on the importance of parental socialization and influence on the financial capability of emerging adults. Dr. Jorgensen received his Ph.D. in Human Development and Family Studies at Virginia Tech.

David B. Allsop is a graduate student in the Master's in Marriage Family and Human Development at Brigham Young University. His research focuses on healthy sexual relationships in marriage, healthy marital relationships, and family finance. He is a Certified Nonprofit Professional and will soon receive his designation as a Certified Family Life Educator. He plans to become a professor of family life to promote strong family relationships.

Sam Runyan is a graduate master's student currently studying to be a school counselor at Idaho State University. Sam worked as a research assistant aiding in the authorship of several works dedicated to family finance. He graduated from Brigham Young University with a bachelor degree in Family Life.

Brandan E. Wheeler Ph.D., is an assistant professor in the School of Human Sciences at Mississippi State University, specializing in Family Resource Management. He currently teaches courses in consumer economics, family resource management, family policy, and intimate relationships, while his research focuses on how finances influence couple relationships, especially among young adult romantic relationships. He received his Ph.D. in Human Development and Family Studies from Auburn University.

David A. Evans is a Continuing Lecturer and Certified Financial Planning Program Director in the department of Consumer Science at Purdue University. David has published and presented on financial help seeking behaviors among married couples and the savings behaviors of low-income households. Dr. Evans received his Ph.D. in Family Resource Management from The Ohio State University.

Loren D. Marks is a Professor in the School of Family Life at Brigham Young University. He has centered his qualitative research efforts on families and religion, while also exploring families and finances. He received his Ph.D. in Family Studies from the University of Delaware. 